\title{
Tree Nitrogen Status and Leaf Canopy Position Influence Postharvest Nitrogen Accumulation and Efflux from Pear Leaves
}

\author{
Enrique E. Sanchez' and Timothy L. Righetti ${ }^{2}$ \\ Department of Horticulture, Oregon State University, Corvallis, OR 97331 \\ Additional index words. Pyrus communis, ${ }^{15} \mathrm{~N}$, partitioning, recycling
}

\begin{abstract}
Cornice' pear trees (Pyrus communis $\mathbf{L}$.) were fertilized with ammonium nitrate depleted in ' $\mathbf{N}$ in Spring 1987 and 1988. In Aug., Oct., and Nov. 1988, midleaves on current season shoots were sampled at three positions from the periphery to the center of the canopy. Total N/cm' of leaf area remained almost constant through October, even though percent $N$ concentration declined as specific leaf weight (SLW) increased. Furthermore, there was no substantial net change in either labeled or unlabeled $N$ in either treatment until senescence began in October. Peripheral leaves contained higher levels of both reserve and newly acquired $\mathbf{N}$ than did less-exposed leaves. Despite large differences in $\mathrm{N} / \mathrm{cm}^{2}$ for October samples, by November leaves from both high (HN) and low N (LN) trees exported similar percentages of their total $\mathbf{N}$. The average $\mathbf{N}$ export to storage tissues irrespective of tree $\mathbf{N}$ status was $71 \%, 61 \%$, and $52 \%$ for peripheral, medium, and interior leaves, respectively. The export of $\mathrm{N}$ was influenced more by the leaf position in the plant canopy than the nutritional status of the tree.
\end{abstract}

Early spring growth in fruit trees depends heavily on tree $\mathrm{N}$ reserves (Oland, 1959; Taylor, 1967; Titus and Kang, 1982). However, the dynamics of how this reserve $\mathrm{N}$ is translocated from leaves to storage tissues in late summer and early fall is not fully understood. After 'Cornice' pears are harvested, typically during the first week of September, leaves transpire and remain photosynthetically active before senescence begins in October. Nitrogen accumulation and remobilization during this postharvest period has important physiological consequences in the tree. Castagnoli et al. (1990) demonstrated in peach and nectarine that leaf $\mathrm{N}$ remobilization ranged from $45 \%$ to $50 \%$ irrespective of $\mathrm{N}$ status, but little is known about how $\mathrm{N}$ status and canopy position affect $\mathrm{N}$ dynamics.

The distribution of light within fruit trees clearly influences leaf physiology (Barden, 1974; Barden, 1977; DeJong, 1982; DWong and Doyle, 1985; Jackson, 1980; Marini and Marini, 1983; Porpiglia and Barden, 1980). Previous research has addressed the effect of light on photosynthesis (DeJong, 1982, 1983; Marini and Barden, 1982), dark respiration, (Barden, 1974, 1977; Porpiglia and Barden, 1980), chlorophyll content (Kappel and Flore, 1983; Marini and Marini, 1983), and SLW (Barden, 1974, 1977; Marini and Barden, 1982; Wooge and Barden, 1987). However, light influences the distribution of $\mathrm{N}$ as well, and there is a strong positive relationship between leaf N/ $\mathrm{cm}^{2}$ leaf area and photosynthetic capacity (DeJong, 1982; DeJong and Doyle, 1985). In peach and other Prunus species, both photosynthetic $\mathrm{CO}_{2}$ assimilation and mesophyll conductance are linearly related to N/ $\mathrm{cm}^{2}$ (DeJong, 1982; DeJong and Doyle, 1985). In view of the association between leaf position in the canopy with leaf $\mathrm{N} / \mathrm{cm}^{*}$ and photosynthetic capacity, we suspected that light exposure might also affect net $\mathrm{N}$ accumulation and efflux.

Shading reduces both $\mathrm{N} / \mathrm{cm}^{2}$ and $\mathrm{N}$ as a percentage of dry

\footnotetext{
Received for publication 21 Aug. 1989. Oregon Agricultural Experiment Station Paper no. 8993. Part of a thesis to be submitted by the senior author in fulfillment of the requirements for the $\mathrm{PhD}$ degree. The cost of publishing this paper was defrayed in part by the payment of page charges. Under postal regulation, this paper therefore must be hereby marked advertisement solely to indicate this fact.

'INTA Alto Vane, CC 782, 8332 General Rota, Argentina.

${ }^{2}$ Associate Professor.
}

weight (DeJong et al., 1989). Weinbaum et al. (1989) reported that mineral weight per unit of leaf area increased with increasing photosynthetic photon flux, but leaf nutrient concentration expressed as percent dry matter did not. However, most information has been gathered with stone fruits; pome fruits still need evaluation. Our objectives were to 1) determine the extent of $\mathrm{N}$ accumulation in 'Cornice' pear leaves during the late fruit maturation and postharvest period and 2) evaluate how tree $\mathrm{N}$ status and canopy position affect accumulation and efflux of $\mathrm{N}$ from leaves.

\section{Materials and Methods}

We used 6-year-old 'Cornice' pear trees on BA-29 quince rootstock trained to a central leader. Trees were spaced $2.3 \mathrm{x}$ $5.4 \mathrm{~m}$, with rows oriented east to west on a Central Point sandy loam soil in Medford, Ore. In May 1987, 13 individual trees were fertilized with $180 \mathrm{~g} \mathrm{~N}$, applied in the form of ammonium nitrate depleted in $15 \mathrm{~N}\left(0.01\right.$ atom percent $\left.{ }^{15} \mathrm{~N}\right)$. Eight of 13 trees were removed at the end of the first season and new trees were replanted at the same location. Isotopic analysis of these young trees and barley seedlings planted adjacent to the trunks of five other similarly treated trees did not reveal significant labeled $\mathrm{N}$ from the previous season. The remaining five trees were not refertilized in 1988. Thus, despite the large application in 1987, the $\mathrm{N}$ status of these young growing trees was low in 1988.

In 1988, 1 month before bloom, another set of five trees was fertilized with $120 \mathrm{~g}$ of ammonium nitrate-N, similarly depleted in ${ }^{15} \mathrm{~N}$. Since the plot was frost-protected with overhead sprinklers before and during bloom, an additional $70 \mathrm{~g}$ of nonlabeled $\mathrm{N}$ was broadcast under the tree canopy the week after bloom to assure high levels of soil $\mathrm{N}$ and, therefore, HN status. The former treatment (1987) is referred to as LN and the second is referred to as $\mathrm{HN}$. We were more concerned with establishing different $\mathrm{N}$ status than attempting to label soil and within-tree storage pools. Although there is unequal labeling, we have a clear case where we can compare labeled trees growing in $\mathrm{LN}$

$\overline{\text { Abbreviations: }}$ HN, high N; LN, low N; NFF, N derived from fertilizer; SLW, specific leaf weight. 
conditions (without additional label) with $\mathrm{HN}$ trees obtaining labeled $\mathrm{N}$ during the current season.

On 20 Aug., 10 Oct., and 18 Nov. 1988, midshoot leaves on current season shoots were sampled from all tree sides between 1.5 and $2.0 \mathrm{~m}$ above ground level in three positions of the canopy from the periphery to the center of the tree. Light was measured at midday in August at all three positions of the canopy with a quantum sensor (LI-188B, LI-COR Inc., Lincoln, $\mathrm{Neb}$ ). Leaves received an average of $68 \%, 41 \%$, and $22 \%$ of full sunlight for peripheral, medium, and interior leaves, respectively. Ten leaf disks $\left(1.03 \mathrm{~cm}^{2}\right.$ each) were punched with a sharp cork borer from vein-free regions of five leaves at each position on five single trees per treatment. All samples were collected at the same time of day. The leaf disks were dried at $60 \mathrm{C}$ for $24 \mathrm{hr}$ and weighed to permit calculation of SLW. Current year shoots were also sampled in August and October from the peripheral canopy of LN trees and divided into bark, wood, and leaves from the upper and lower portion of the shoot. Adjacent branches of similar size were used for the two sampling times.

Nitrogen content was measured using a Technicon AutoanaIyzer after micro-Kjeldahl digestion in an aluminum block. Aliquots of the digest containing. at least $1 \mathrm{mg} \mathrm{N}$ were used for ammonium separation following the diffusion technique described by MacKown et al. (1987). Samples were diffused at room temperature for 3 weeks before the isotopic composition was determined by mass spectrometry at Isotope Services, Los Alamos, N.M. Atom percent values were converted to NFF using standard conversions (Hauck and Bremner, 1976).

Each treatment was applied to randomly selected trees in the orchard. The data were analyzed as both a split split-plot and completely randomized experiment with a factorial arrangement of treatments. When treated as a split split-plot, we had $\mathrm{N}$ treatments as main plots (factor A). Therefore, the levels of factor $\mathrm{B}$ (time) are randomized within each treatment, and the levels of factor C (canopy position) are randomized within each time. To 'deal with the theoretical, problems with split split-plot in time, we also modified the analysis to pull out the time $\mathrm{x}$ block interaction instead of pooling it into error b. Significant main effects and interactions do not change regardless of the statistical approach. Therefore, only the results of the completely randomized statistical evaluation are shown.

\section{Results and Discussion}

Uptake of labeled fertilizer $\mathrm{N}$ in the $\mathrm{HN}$ treatment did not persist throughout the entire season. The percentage of $\mathrm{N}$ that was labeled in leaves increased rapidly early in the season, reached a peak of $19 \% 2$ weeks after bloom, and then declined steadily until August (Sanchez et al., 1990). This suggests that nonlabeled soil $\mathrm{N}$ was the major $\mathrm{N}$ source after the first month, and $\mathrm{HN}$ trees accumulated almost all of their label early in the season. The $\mathrm{HN}$ treatment was a pulse of labeled $\mathrm{N}$ rather than a continuous supply.

Since leaf area remains constant near harvest (Cain, 1973), SLW and $\mathrm{N} / \mathrm{cm}^{2}$ are good indicators of biomass and $\mathrm{N}$ changes in the leaves. SLW in both treatments was highest in October (Figs. 1 and 2). Apple SLW also increased throughout the season (Brown et al., 1985; Wooge and Barden, 1987). Castagnoli et al., 1990) recently reported a general trend of increasing SLW from midseason until late in the season in peach and nectarine. Increases in leaf carbohydrates, especially starch, result from low demand by other parts of the tree during late season and likely explain differences in SLW (Brown et al., 1985). Patterns

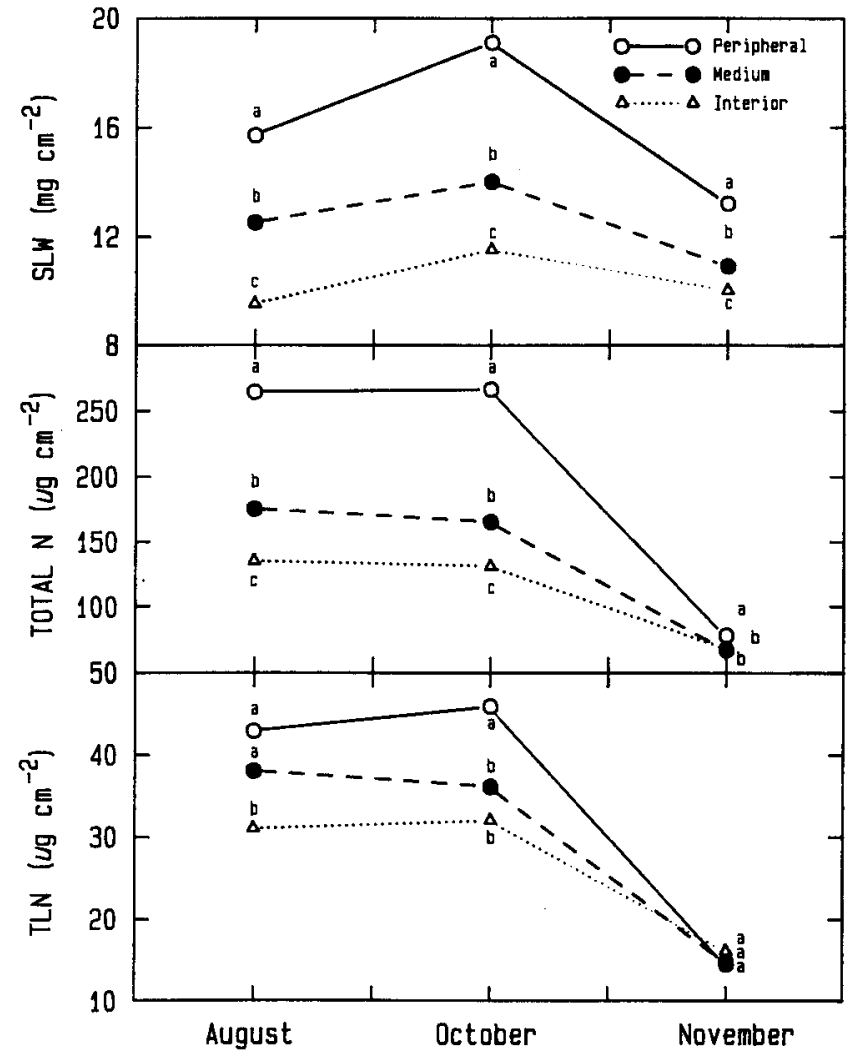

Fig. 1. Seasonal changes in SLW, total $\mathrm{N} / \mathrm{cm}^{2}$, and total labeled $\mathrm{N}$ $(\mathrm{TLN}) / \mathrm{cm}^{2}$ for pear leaves as influenced by canopy position. Trees were fertilized with depleted ${ }^{15} \mathrm{~N}$ in May 1987 (LN treatment); therefore, all label is from tree reserves. Mean separation for each month by least significant difference $(\mathrm{P}<0.05)$.

for $\mathrm{HN}$ and $\mathrm{LN}$ trees were similar. However, SLW values for LN were higher than for HN for peripheral leaves (Figs. 1 and 2). Increasing SLW with decreasing $N$ availability has been observed in other species (DeJong, 1989; Gulmon and Chu, 1981) and may relate to increases in the cell wall fraction (Radin and Parker, 1979). It should be stressed that LN trees were not $\mathrm{N}$ deficient. Shoot growth was normal and 'Cornice' on quince rootstock have low $\mathrm{N}$ content, with values as low as $1.7 \% \mathrm{~N}$ from high-yielding trees (P.B. Lombard and E.E. Sanchez, unpublished), and the long-term average for 'Cornice' is $1.80 \%$ (Plant Analysis Laboratory, Oregon State Univ., unpublished).

Position $\mathrm{x}$ time interactions were significant (Table 1), suggesting that SLW increases to a greater degree in the more exposed, and presumably more photosynthetically active, leaves. Although total N/cm $\mathrm{cm}^{2}$ remained almost constant between August and October (Figs. 1 and 2), N concentration decreased substantially during this period (Table 2). This decrease is not attributable to $\mathrm{N}$ export but to increases in SLW. DeJong (1986) reported similar results in peach. Total labeled $\mathrm{N}$ per unit of area $\left(\mathrm{TLN} / \mathrm{cm}^{2}\right)$ remained almost constant for all leaf positions between August and October (Figs. 1 and 2). TLN $/ \mathrm{cm}^{2}$ was significantly greater in peripheral leaves than in medium and interior leaves (Fig. 1). The percentage labeled $\mathrm{N}$ in bark and wood (LN treatment) did not vary with position in well-exposed peripheral shoots (Table 3 ). However, leaves significantly differed in their percentage of labeled $\mathrm{N}$, suggesting that distal leaves (younger) were more dependent on newly acquired $\mathrm{N}$ than were the proximal. No net change in $\mathrm{N}$ occurred until senescence began in October. Although leaves are transpiring 


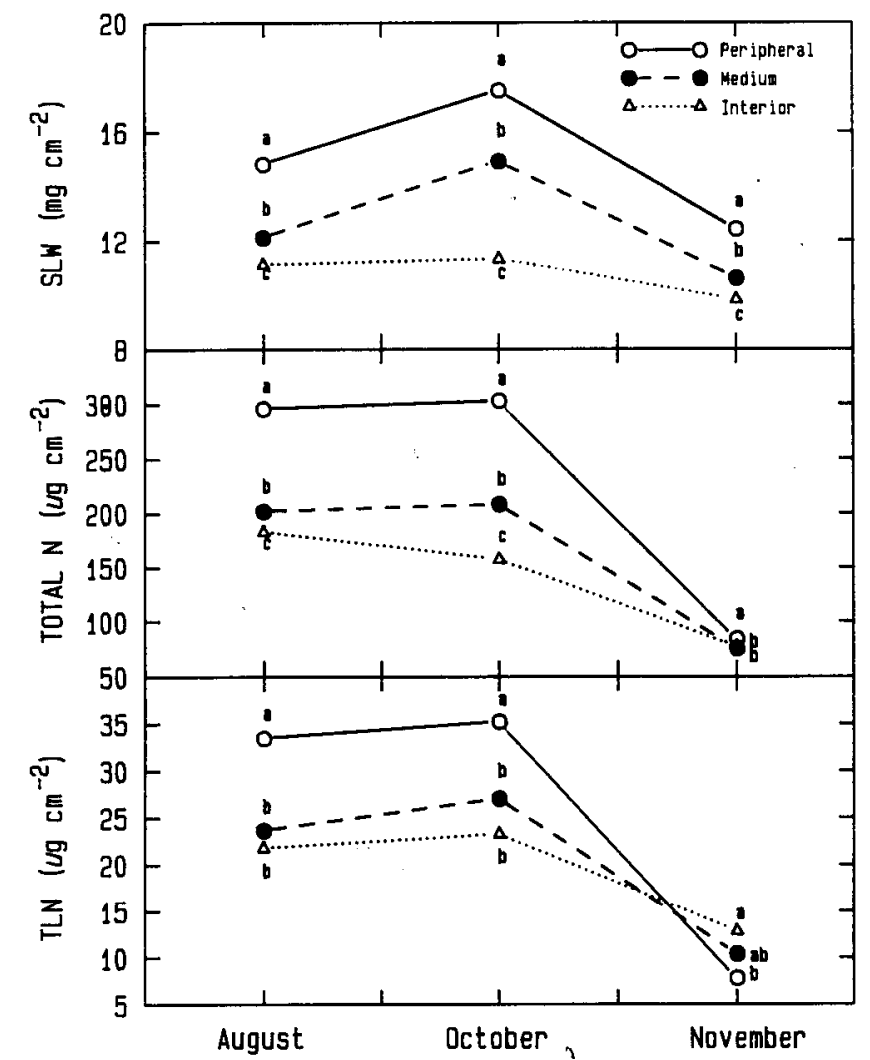

Fig. 2. Seasonal changes in SLW, total $\mathrm{N} / \mathrm{cm}^{2}$, and total labeled $\mathrm{N}$ $(\mathrm{TLN}) / \mathrm{cm}^{2}$ for pear leaves as influenced by canopy position. Trees were fertilized with depleted ${ }^{15} \mathrm{~N}$ in Mar. 1988 (HN treatment); therefore, all label is from the uptake of current application. Mean separation by least significant difference $(P<0.05)$.

Table 1. Main effects and interactions for SLW, N concentration, total $\mathrm{N}$ per unit of leaf area $\left(\mathrm{TN} / \mathrm{cm}^{2}\right)$, and total labeled $\mathrm{N}$ per unit of leaf area $\left(\mathrm{TLN} / \mathrm{cm}^{2}\right)$. Data were analyzed as a completely randomized design.

\begin{tabular}{lcccc}
\hline \hline & SLW & N (\% dry wt) & TN $/ \mathrm{cm}^{2}$ & TLN $/ \mathrm{cm}^{2}$ \\
\hline Time (T) & $* * *$ & $* * *$ & $* * *$ & $* * *$ \\
Treatment (Tmt) & NS & $* * *$ & $* * *$ & $* * *$ \\
Position (Pos) & $* * *$ & $* * *$ & $* * *$ & $* * *$ \\
Time $\times$ Tmt & NS & $* * *$ & $* * *$ & NS \\
Time $\times$ Pos & $* * *$ & $* * *$ & $* * *$ & $*$ \\
Tmt $\times$ Pos & $* *$ & $*$ & NS & NS \\
T $\times$ Pos $\times$ Tmt & $*$ & NS & NS & NS \\
\hline
\end{tabular}

NS, ${ }^{*}, * *, * * *$ Nonsignificant or significant at $P<0.05,0.01$, or 0.001 , respectively.

Table 2. Nitrogen concentration (percent dry-matter basis) within the canopy in midshoot leaves of trees receiving labeled $\mathrm{N}$ in 1987 (LN) and $1988(\mathrm{HN})$, respectively.

\begin{tabular}{|c|c|c|c|c|c|c|}
\hline \multirow{3}{*}{$\begin{array}{l}\text { Leaf } \\
\text { position }\end{array}$} & \multicolumn{6}{|c|}{$\mathrm{N}^{2}(\%)$} \\
\hline & \multicolumn{2}{|c|}{ August } & \multicolumn{2}{|c|}{ October } & \multicolumn{2}{|c|}{ November } \\
\hline & LN & $\mathrm{HN}$ & $\mathrm{LN}$ & $\mathrm{HN}$ & $\mathrm{LN}$ & $\mathrm{HN}$ \\
\hline Interior & $1.40 \mathrm{~b}$ & $1.64 \mathrm{~b}$ & $1.14 \mathrm{~b}$ & $1.33 \mathrm{c}$ & $0.69 \mathrm{a}$ & $0.80 \mathrm{a}$ \\
\hline Medium & $1.40 \mathrm{~b}$ & $1.64 \mathrm{~b}$ & $1.19 \mathrm{~b}$ & $1.39 \mathrm{~b}$ & $0.63 \mathrm{~b}$ & $0.73 \mathrm{~b}$ \\
\hline Peripheral & $1.69 \mathrm{a}$ & $2.00 \mathrm{a}$ & $1.36 \mathrm{a}$ & $1.74 \mathrm{a}$ & $0.59 \mathrm{~b}$ & $0.69 \mathrm{~b}$ \\
\hline
\end{tabular}

${ }^{7}$ Numbers within a column followed by the same letter are not significantly different (LSD, $P<0.05 ; \mathrm{n}=5$ ).
Table 3. Partitioning of ${ }^{15} \mathrm{~N}$ depleted fertilizer in bark, wood, and leaves from the LN treatment in August and October for upper and bottom portions of current season peripheral shoots.

\begin{tabular}{|c|c|c|c|c|c|c|}
\hline \multirow{3}{*}{$\begin{array}{l}\text { Shoot } \\
\text { location }\end{array}$} & \multicolumn{6}{|c|}{$\mathrm{N}$ derived from ${ }^{15} \mathrm{~N}$ fertilizer ${ }^{2}(\%)$} \\
\hline & \multicolumn{2}{|c|}{ Bark } & \multicolumn{2}{|c|}{ Wood } & \multicolumn{2}{|c|}{ Leaves } \\
\hline & August & October & August & October & August & October \\
\hline Upper & $16.2 \mathrm{a}$ & $16.0 \mathrm{a}$ & $15.4 \mathrm{a}$ & $15.8 \mathrm{a}$ & $16.4 \mathrm{a}$ & $16.8 \mathrm{a}$ \\
\hline Bottom & $17.8 \mathrm{a}$ & $16.6 \mathrm{a}$ & $14.0 \mathrm{a}$ & $15.5 \mathrm{a}$ & $20.6 \mathrm{a}$ & $20.8 \mathrm{~b}$ \\
\hline
\end{tabular}

'Numbers followed with the same letter for an individual tissue are not significantly different (LSD, $P<0.05 ; \mathrm{n}=5$ ).

Table 4. Nitrogen derived from ${ }^{15} \mathrm{~N}$ depleted fertilizer within the canopy in midshoot leaves of trees receiving labeled $\mathrm{N}$ in 1987 (LN).

\begin{tabular}{lllc}
\hline \hline $\mathrm{L}$ e a f & \multicolumn{3}{c}{$\mathrm{N}$ derived from ${ }^{15} \mathrm{~N}$ fertilizer ${ }^{2}(\%)$} \\
\cline { 2 - 4 } position & August & October & November \\
\hline Interior & $22.8 \mathrm{a}$ & $24.0 \mathrm{a}$ & $22.6 \mathrm{a}$ \\
Medium & $21.4 \mathrm{a}$ & $21.3 \mathrm{~b}$ & $21.0 \mathrm{a}$ \\
Peripheral & $15.8 \mathrm{~b}$ & $17.0 \mathrm{c}$ & $18.3 \mathrm{~b}$ \\
\hline
\end{tabular}

'Numbers within a column followed by the same letter are not significantly different (LSD, $P<0.05 ; \mathrm{n}=5$ ). Time and time $\mathrm{x}$ position are not significant.

and physiologically active, there is no substantial change in either labeled or unlabeled $\mathrm{N}$ accumulation or efflux. If there is $\mathrm{N}$ uptake during the postharvest period, it does not appear to be translocated to the leaves (Weinbaum et al., 1984; Sanchez, 1990), even though the label can be found in the roots during the dormant season (Sanchez, 1990).

Once export of $\mathrm{N}$ began, all three canopy positions decreased to a similar level of total $\mathrm{N} / \mathrm{cm}^{*}$, with peripheral leaves having only a slightly higher $\mathrm{N}$ value when expressed on an area basis (Figs. 1 and 2). On a percentage dry-weight basis, peripheral and medium leaves were clearly lower in $\mathrm{N}$ than the interior leaves in November (Table 2). Despite differing in SLW, senescent leaves from different parts of the canopy were much closer with respect to $\mathrm{N} / \mathrm{cm}^{2}$. Differences in $\mathrm{N}$ status of senescent leaves were greater when expressed on a dry-matter basis than when expressed on an area basis.

NFF reveals how canopy position affected leaf partitioning of stored vs. soil-derived $\mathrm{N}$ (Table 4). Values for the LN treatment are easier to interpret because all of the label was acquired the previous year and differences in leaf values represent differences between the use of stored and soil $\mathrm{N}$ pools. The $\mathrm{HN}$ values (not shown) are harder to interpret, because lower values can either mean more tree reserve use early in the uptake period or a greater uptake of unlabeled soil $\mathrm{N}$ late in the uptake period.

In August, LN trees had the highest percent NFF for interior and medium leaves and the lowest for peripheral ones (Table 4). This suggests that peripheral leaves were more dependent on newly acquired $\mathrm{N}$, leaving them less enriched in the labeled $\mathrm{N}$ that comes from reserves.

Since the first $\mathrm{N}$ coming to leaf tissues is structural rather than photosynthetically functional, the $\mathrm{N}$ that enters the leaf earliest during leaf development may be most difficult to remobilize. Previous studies on almonds (Weinbaum et al., 1984) and our own evaluations on pear (Sanchez et al., 1990) suggest that leaves depend on reserve $\mathrm{N}$ for their initial $\mathrm{N}$ accumulation. If leaf $\mathrm{N}$ accumulated later in the season is preferentially derived from the soil, we would expect the leaf to preferentially export the soil-derived $\mathrm{N}$ and retain the $\mathrm{N}$ accumulated earliest, i.e., from tree reserves. 
Retranslocation of $\mathrm{N}$ to storage tissues presumably occurred after the 1st week of October (i.e., coincident with leaf $\mathrm{N}$ remobilization). Leaf remobilization varied among the different canopy positions. The average $\mathrm{N}$ efflux per unit of area for both treatments was $71 \%, 61 \%$, and $52 \%$ for peripheral, medium, and interior leaves, respectively (Figs. 1 and 2). Also, peripheral and medium leaves in both treatments exported exactly the same proportion of their total $\mathrm{N}(71 \%$ and $62 \%)$ in spite of the differential $\mathrm{N}$ status. The export from interior leaves differed slightly with treatment (48\% vs. $56 \%$ for $\mathrm{LN}$ and $\mathrm{HN}$ treatments, respectively). This result suggests that the export of $\mathrm{N}$ is more influenced by the light exposure than by the nutritional status of the tree. The differences observed in percent $\mathrm{N}$ in November between $\mathrm{LN}$ and $\mathrm{HN}$ are due again to differences in SLW since the total $\mathrm{N}$ per unit of area was similar. In our study, interior leaves from $\mathrm{HN}$ trees have $26 \%$ more $\mathrm{N}$ than do interior leaves of the LN treatment (Figs. 1 and 2). The results agree with recent studies where $\mathrm{N}$-fertilized peach trees have substantially more $\mathrm{N} / \mathrm{cm}^{2}$ in similar canopy positions than unfertilized trees (DeJong et al., 1989).

In summary, regardless of how the $\mathrm{N}$ was delivered to the leaves, via tree reserves or from the soil, efflux patterns were similar for LN and $\mathrm{HN}$ conditions. No net change in $\mathrm{N}$ content or isotopic composition occurred until senescence began. Nitrogen did not increase in any of the leaves regardless of canopy position or tree $\mathrm{N}$ status. Interestingly, peripheral and middle leaves in both treatments exported exactly the same proportion of their total $\mathrm{N}$ in spite of differential $\mathrm{N}$ status. This relationship suggests that the export of $\mathrm{N}$ is more influenced by light exposure than by nutritional status of the tree.

\section{Literature Cited}

Barden, J.A. 1974. Net photosynthesis, dark respiration, specific leaf weight, and growth of young apple trees as influenced by light regime. J. Amer. Soc. Hort. Sci. 99:547-551.

Barden, J.A. 1977. Apple tree growth, net photosynthesis, dark respiration, and specific leaf weight as affected by continuous and intermittent shade. J. Amer. Soc. Hort. Sci. 102:391-394.

Brown, C. S., E. Young, and D.M. Pharr. 1985. Rootstock and scion effects on carbon partitioning in apple leaves. J. Amer. Soc. Hort. Sci. 110:701-705.

Cain, J.C. 1973. Foliage canopy development of 'McIntosh' apple hedgerows in relation to mechanical pruning, the interception of solar radiation, and fruiting. J. Amer. Soc. Hort. Sci. 98:357-360.

Castagnoli, S. P., T.M. DeJong, S.A. Weinbaum, and R.S. Johnson. 1990. Autumn foliage applications of $\mathrm{ZnSO}_{4}$. reduced leaf nitrogen remobilization in peach and nectarine. J. Amer. Soc. Hort. Sci. 115:79-83.

DeJong, T.M. 1982. Leaf nitrogen content and $\mathrm{CO}_{2}$ assimilation capacity in peach. J. Amer. Soc. Hort. Sci. 107:955-959.

DeJong, T.M. 1983. $\mathrm{CO}_{2}$ assimilation characteristics of five Prunus tree fruit species. J. Amer. Soc. Hort. Sci. 108:303-307.
DeJong, T.M. and J.F. Doyle. 1985. Seasonal relationships between leaf nitrogen content (photosynthetic capacity) and leaf canopy light exposure in peach (Prunus persica). Plant Cell \& Env. 8:701-706.

DeJong, T. M., K.R. Day, and R.S. Johnson. 1989. Partitioning of leaf nitrogen with respect to within canopy light exposure and nitrogen availability in peach (Prunus persica). Trees 3:89-95.

Gulmon, S.L. and C.C. Chu. 1981. The effects of light and nitrogen on photosynthesis, leaf characteristics, and dry matter allocation in the chaparral shrub, Diplacus aurantiacus. Oecologia 49:207-212.

Hauck, R.D. and J,M. Bremner. 1976. Use of tracers for soil and fertilizer nitrogen research. Adv. Agron. 28:219-266.

Jackson, J.E. 1980. Light interception and utilization by orchard systems. Hort. Rev. 2:208-267.

Kappel, F. and J.A. Flore. 1983. Effect of shade on photosynthesis, specific leaf weight, leaf chlorophyll content, and morphology of young peach trees. J. Amer. Soc. Hort. Sci. 108:541-544.

MacKown, C. T., P.D. Brooks, and M.S. Smith. 1987. Diffusion of nitrogen-15 Kjeldahl digest for isotope analysis. Soil Sci. Soc. Amer. J. 51:87-90.

Marini, R.P. and J.A. Barden. 1982. Light penetration on overcast and clear days, and specific leaf weight in apple trees as affected by summer or dormant pruning. J. Amer. Soc. Hort. Sci. 107:39-43.

Marini, R.P. and M.C. Marini. 1983. Seasonal changes in specific leaf weight, net photosynthesis, and chlorophyll content of peach leaves as affected by light penetration and canopy position. J. Amer. Soc. Hort. Sci. 108:600-605.

Oland, K. 1959. Nitrogenous reserves of apple trees. Physiol. Plant. 12:594-648.

Porpiglia, P.J. and J.A. Barden. 1980. Seasonal trends in net photosynthetic potential, dark respiration, and specific leaf weight of apple leaves as affected by canopy position. J. Amer. Soc. Hort. Sci. 105:920-923.

Radin, J.W. and L.L. Parker. 1979. Water relations of cotton plants under nitrogen deficiency. L Dependence upon leaf structure. Plant Physiol. 64:495498.

Sanchez, E.E. 1990. Nitrogen dynamics in field grown Cornice pears. PhD Diss., Oregon State Univ., Corvallis.

Sanchez, E. E., T.L. Righetti, D. Sugar, and P.B. Lombard. 1990. Seasonal differences and soil texture alter uptake of newly absorbed nitrogen in field grown pear trees. J. Hort. Sci. (In press.)

Taylor, B.K. 1967. Storage and mobilization of nitrogen in fruit trees: A review. J. Austral. Inst. Agr. Sci. 33:23-29.

Titus, J.S. and S. Kang. 1982. Nitrogen metabolism, translocation, and recycling in apple trees. Hort. Rev. 4:204-246.

Weinbaum, S. A., 1. Klein, F.E. Broadbent, W.C. Micke, and T.T. Muraoka. 1984. Effects of time of nitrogen application and soil texture on the availability of isotonically labeled fertilizer nitrogen to reproductive and vegetative tissue of mature almond trees. J. Amer. Soc. Hort. Sci. 109:339-343.

Weinbaum, S, A., S.M. Southwick, K.A. Shackel, T.T. Muraoka, W. Krueger, and J.T. Yeager. 1989. Photosynthetic photon flux influences macroelement weight and leaf dry weight per unit of area in prune tree canopies. J. Amer. Soc. Hort. Sci. 114:720-723.

Wooge, J.D. and J.A. Barden. 1987. Seasonal changes in specific leaf weight and leaf anatomy of apple. HortScience 22:292-294. 